\title{
Dissolved carbon in a large variety of lakes across five limnetic regions in China
}

Article

Accepted Version

Song, K., Wen, Z., Xu, Y., Yang, H., Lyu, L., Zhao, Y., Fang, C., Shang, Y. and Du, J. (2018) Dissolved carbon in a large variety of lakes across five limnetic regions in China. Journal of Hydrology, 563. pp. 143-154. ISSN 0022-1694 doi: https://doi.org/10.1016/j.jhydrol.2018.05.072 Available at https://centaur.reading.ac.uk/80025/

It is advisable to refer to the publisher's version if you intend to cite from the work. See Guidance on citing.

To link to this article DOI: http://dx.doi.org/10.1016/j.jhydrol.2018.05.072

Publisher: Elsevier

All outputs in CentAUR are protected by Intellectual Property Rights law, including copyright law. Copyright and IPR is retained by the creators or other copyright holders. Terms and conditions for use of this material are defined in the End User Agreement.

\section{www.reading.ac.uk/centaur}

\section{CentAUR}

Central Archive at the University of Reading 
Reading's research outputs online 


\title{
Dissolved carbon in a large variety of lakes across five limnetic regions in China
}

\author{
Kaishan Song ${ }^{\mathrm{a}, 1, *}$, Zhidan Wen ${ }^{\mathrm{a}, 1}$, Yijun $\mathrm{Xu}^{\mathrm{a}, \mathrm{b}}$, Hong Yang ${ }^{\mathrm{c}}$, Lili Lyu ${ }^{\mathrm{a}}$, Ying \\ Zhao $^{\mathrm{a}, \mathrm{d}}$, Chong Fang ${ }^{\mathrm{a}, \mathrm{d}}$, Yingxin Shang ${ }^{\mathrm{a}, \mathrm{d}}, \mathrm{Jia} \mathrm{Du}^{\mathrm{a}}$ \\ ${ }^{a}$ Northeast Institute of Geography and Agroecology, CAS, Changchun 130102, China \\ ${ }^{\mathrm{b}}$ Environmental Studies Department, Louisiana State University, Baton Rouge, LA, USA \\ c Norwegian Institute of Bioeconomy Research, Pb115, NO-1431 As, Norway \\ ${ }^{\mathrm{d}}$ University of Chinese Academy of Sciences, Beijing 100049, China \\ * Corresponding author. \\ E-mail address: songks@ neigae.ac.cn (K. Song). \\ ${ }^{1}$ These authors contributed equally to this work.
}

\begin{abstract}
Dissolved carbon in lakes play a vital role in the global carbon cycling. The concentration and dynamics of lake dissolved carbon can be influenced by both the surrounding landscape and a combination of physical, chemical and biological processes within the lakes themselves. From 2009 to 2016, we conducted a large-scale assessment of dissolved organic carbon (DOC) and dissolved inorganic carbon (DIC) in 249 lakes across a diverse range of climatic, geopedologic, topographical and hydrological conditions in five Chinese limnetic regions: the East Limnetic Region (ELR), the Northeast Limnetic Region (NLR), the Inner Mongolia-Xinjiang Limnetic Region (MXR), the Yungui Limnetic Region (YGR), and the Tibet-Qinghai Limnetic Region (TQR). We found that the density of the organic matter in the soil in the surrounding landscape plays an important role in the DOC and DIC in lake water, as was evidenced by the high DOC and DIC levels in the NLR, where the soil is respectively organically rich. Conditions in the arid and semi-arid environments (i.e. TQR and MXR) have created a number of brackish/saline lakes and here we found that, DOC and DIC levels (median: 21.79 and $93.72 \mathrm{mg} / \mathrm{L}$, respectively) are significantly higher than those in the freshwater lakes (median: 5.80 and $29.38 \mathrm{mg} / \mathrm{L}$ ). It also appears to be the case that the trophic state of freshwater lakes influences the spatial variation of DOC. This can be seen in the relationships between DOC and trophic state index (TSI) in agriculturallydominated regions such as the ELR $\left(\mathrm{R}^{2}=0.59, \mathrm{p}<0.01\right)$, NLR $\left(\mathrm{R}^{2}=0.65, \mathrm{p}<0.001\right)$, and YGR $\left(\mathrm{R}^{2}=0.78, \mathrm{p}<0.001\right)$. Additionally, a close relationship between DOC and DIC can be found in lake waters with different trophic states (eutrophic: slp $=0.63, \mathrm{R}^{2}=$ 0.69; mesotrophic: $\mathrm{slp}=1.03, \mathrm{R}^{2}=0.65$; oligotrophic: $\mathrm{slp}=1.00, \mathrm{R}^{2}=0.64$ ). This indicates that human activities influence the quantity and quality of dissolved carbon in inland water across China. This study is able to provide insights regarding the potential effects of climate change and changes in land-use upon the amount of dissolved carbon in lake water.
\end{abstract}

\section{Introduction}

Dissolved carbon (DC) in water bodies, including both dissolved organic carbon (DOC) and its inorganic counterpart, dissolved in- organic carbon (DIC), play a vital role in the global carbon cycle (Cole et al., 2007; Tranvik et al., 2009; Borge et al., 2015; Weyhenmeyer et al., 2015). Although, inland waters cover only a small fraction of the earth's surface, they have a disproportionately large effect on this cycle (Cole et al., 2007; Armstrong, 2010; Catalan et al., 2016) 
through the storing and decomposing organic matter-and the emission of green-house gases (Cole et al., 1994; Raymond et al., 2013). Hydrologically, lakes receive the water from the surrounding landscape and therefore, according to Armstrong (2010), a large amount of the carbon produced by terrestrial systems ends up in inland waters in the form of particulates, where it is stored and/or mineralized and released back into the atmosphere as $\mathrm{CO}_{2}$ and $\mathrm{CH}_{4}$. DOC is one of the largest bioactive organic reservoirs on the earth's surface (Cole et al., 2007; Para et al., 2010), and is the main substrate for heterotrophic bacterial growth. The mineralization of DOC through biodegradation or photodegradation is a major source of $\mathrm{CO}_{2}$ in the atmosphere (Tranvik et al., 2009; Butman et al., 2015). In water bodies DOC can mediate the chemical environment through the generation of organic acids (Brooks and Lemon, 2007), and enhance or alleviate the toxicity of heavy metals (Cory et al., 2006). As it is the main component of colored dissolved organic matter, DOC also plays a vital role in regulating the transmission of light in aquatic ecosystems (Karlsson et al., 2009; Song et al., 2013), proving a shield against harmful ultraviolet light and protecting aquatic organisms in the water (Williamson and Rose, 2010).

Environmental and limnological factors, e.g., temperature,- precipitation, lake type, and trophic level, have a major influence on the transport, transformation and storage of DOC in a body of water (Arts et al., 2000; Duarte et al., 2008; Gudasz et al., 2010; Weyhenmeyer et al., 2016; Wen et al., 2018). Previous studies have demonstrated that the DOC in inland waters tends to decrease as the duration time for the water increases because of increased photochemical processes and microbial consumption and decomposition (Hanson et al., 2011; Kellerman et al., 2015). However, studies have also found that inland waters in semi-arid and arid regions with high salinity exhibit elevated DOC concentrations (Brooks and Lemon, 2007; Wen et al., 2016). Curtis and Adams (1995) reported a positive correlation between DOC and specific conductivity in a semi-arid part of eastern-central Alberta in Canada. In another study of DOC in inland waters across the Songnen Plain in Northeastern China, Song et al. (2013) found a strong association between DOC and salinity. The endorheic region of China covers about $42 \%$ of the country's mainland area. This region has many brackish and saline lakes with a total surface area of $46321 \mathrm{~km} 2$, which accounts for $51 \%$ of the country's total lake surface area and $67 \%$ of the country's total lake water volume (Wang and Dou, 1998). The pattern of the spatial distribution of DOC in both fresh and brackish/saline water merits further investigations for carbon cycling, as increasingly postulated by researchers, its potential impact on the global carbon cycle (e.g., Duarte et al., 2008; Raymond et al., 2013; Wen et al., 2016).

DIC is another important component of dissolved carbon in water. DIC generally occurs as dissolved $\mathrm{CO} 2$, bicarbonate $(\mathrm{HCO} 3-)$, and carbonate $(\mathrm{CO} 3-2)$, and it has a direct connection with water $\mathrm{pH}$ and temperature fluctuations (Wetzel, 2001; Pacheco et al., 2013). DIC is the primary source of carbon for photosynthesis and the generation of organic substances. In inland waters, DIC can be derived from mineralization and microbial activity in both the lakes and their drainage basin. The amount of inorganic carbon is determined by the respiratory production of $\mathrm{CO} 2$ by organisms and by the influx of $\mathrm{CO} 2$ and $\mathrm{HCO} 3$ - from incoming water through weathering, atmospheric invasion and ground water (Wetzel, 2001; Raymond et al., 2013). As a major constituent of inland waters, DIC can affect its gaseous characteristics and the availability of nutrients, and it is a fundamental requirement for organic productivity (Marcé et al., 2015). DIC can also regulate acidity, hardness and other related characteristics of the water, affecting in turn light conditions and the availability of nutrients in the water column (Wetzel, 2001). There is also remarkable spatial variation in the amount of DIC in water (i.e., $\mathrm{CO} 2, \mathrm{H} 2 \mathrm{CO} 3-$, and $\mathrm{CO} 32^{-}$) because of variability in terrestrial input, aquatic transformation, and the exchange taking place at air-water interfaces (Duarte et al., 2008). This makes it important to investigate the spatial patterns of DIC distribution in the landscape as this is a major factor regulating the dynamics of DIC distribution in inland water.

In recent decades, a number of studies have explored the spatial and temporal variation of DOC in coastal and fresh inland waters (Sobek et al., 2007; Tranvik et al., 2009; Wen et al., 2016). However, these studies are geographically and climatically rather limited. For instance, in western European countries and especially in Scandinavia, where lakes are abundant, DOC variation has been investigated intensively (Agren et al., 2007; Sobek et al., 2007; Weyhenmeyer et al., 2015). Lakes in North America and Japan have also been examined from this perspective (Curtis and Adams, 1995; Sugiyama et al., 2004; Kawasaki et al., 2013). However, most of these lakes are located in a temperate zone with a relatively low elevation. Comparatively, few investigations have been carried out regarding the spatial variation of DOC and DIC in inland waters across a variety of different climatic,

geopedological and topographical landscape conditions. This is especially true for countries, such as China, where there is a large gradient and variability in climate, elevation, and ecoregion. The Tibetan Plateau is a prime example here. It is the highest plateau in the world, covering a vast land area with 
drastically different geopedological and topographical conditions and ecosystem. The plateau also has an abundance of lakes, especially brackish and saline ones (Wang and Dou, 1998). Little is known about the dissolved carbon in these lakes and this kind of information can provide future studies with a baseline for estimating the effects of climate change on the aquatic carbon cycle at high altitudes and latitudes (Song et al., 2016).

Trophic state has been found to have a strong impact on internal DOC generation and fluctuations in its concentration (Zhang et al., 2010; Pacheco et al., 2013; Zhou et al., 2017). It has also been found that DIC, as a major constituent of inland waters that has a direct or indirect connections with trophic state (Weyhenmeyer et al., 2015), can have an effect upon nutrient availability and the productivity of aquatic systems (Tranvik et al., 2009; Pacheco et al., 2013). In shallow lakes, both DOC and DIC can become partly buried in the lake bottom sediments. Some part of the sedimentary DC will then be lost through mineralization and physiochemical process, particularly when re-suspension is caused by strong winds (Gudasz et al., 2010; Zhou et al., 2015). Given the rapid economic development currently taking place in China, the water quality in many Chinese lakes had been severely impaired by excessive nutrient input. This input arises from both non-point source pollution through various agricultural practices and from point source pollution relating to urbanization and industrial discharge (Ministry of Environment Protection of China: MEPC, 2015; Shi et al., 2018). According to the latest annual report by the MEPC, only $8 \%$ out of the 62 lakes subject to long-term monitoring were oligotrophic, $61 \%$ were mesotrophic, $23 \%$ were eutrophic, and the remaining $8 \%$ were hypereutrophic (Ministry of Environment Protection of China: MEPC, 2015). The serious eutrophication of inland waters may have changed the distribution pattern of DOC in lakes across China. This merits further exploration (Zhang et al., 2010; Zhou et al., 2015; Zhao et al., 2016). DOC and DIC concentrations in inland waters are regulated by a series of environmental parameters, with these parameters varying spatially and across different ecosystems. However, study of this aspect of the DC cycle has not been systematically conducted.

In this paper we present the results of an investigation of landscape level patterns of dissolved carbon across diverse climatic, geopedological, topographical and hydrological conditions. We hypothesize, here, that the DOC and DIC relationship is changing with environmental conditions, the geographical location and the trophic state of lakes all having an important influence on this relationship. We anticipate that our findings will help research to gain a better insight into the distribution of DC snapshot concentrations across a large variety of lakes. More significantly, the study reported here was the first to undertake large-scale quantification of dissolved carbon in inland lakes across China. As such, it provides a baseline for evaluating the effects of climate change and changes in land use change upon levels of dissolved carbon in the future. The specific objectives of the study included (1) assessing the current levels of DOC and DIC in inland lakes across China; (2) identifying the major environmental factors that affect the spatial variability in the distribution of DOC and DIC, thereby offering an opportunity to explore the relationships between major environmental factors and DC concentration; and (3) determining the relationship of DOC and DIC with the trophic conditions in different environments.

\section{Materials and methods}

\subsection{Study area}

Covering a total land area of 9.6 million square kilometers, China has diverse climatic, geopedological, and topographical conditions. The geomorphology is extremely complex, with areas of high relief in the west and low relief in the east, resulting in an overall trend for the major rivers to flow eastward (Fig. 1). The surface features of the country can be grouped into three elevation levels. The first level is represented by the Tibetan Plateau with average elevation of 4000m above sea level (as 1), and where grassland is the dominant form of land cover (Fig. S1). The second level includes regions lying north of the Kunlun Mountains that descend to between 2000 and 1000 m, including the Mongolian Plateau, the Tarim Basin, the Loess Plateau and the Yungui Plateau. The third level, east of the first and the second level, is made up of hills and plains lying mostly below $500 \mathrm{~m}$ asl, with extensive and densely populated alluvial plains where intensive farming practices dominate (Fig. S1). The climate in China differs significantly from region to region and precipitation generally decreases as one moves from the southeast to the northwest (Fig. S2).

China's lake densities vary significantly across its vast territory, mainly controlled by topography and climate (Fig. 1). According to Wang and Dou (1998), these lakes can be divided into five limnetic regions: the East Limnetic Region (ELR), Northeast Limnetic Region (NLR), Inner Mongolia-Xinjiang 
Limnetic Region (MXR), Yungui Limnetic Region (YGR), and Tibet-Qinghai Limnetic Region (TQR). In the NLR, most lakes ( $\sim 60 \%)$ greater than $1 \mathrm{~km} 2$ are distributed on the Songnen Plain, with the rest in the mountainous regions. In the ELR, about 830 lakes with area greater than $1 \mathrm{~km} 2$ are located in the floodplains of the middle and lower Yellow, Yangtze and Huai Rivers. The total lake area is approximately $25170 \mathrm{~km}^{2}$, which account to $25.3 \%$ of the total lake area in China. In the MXR, there are 820 lakes with a surface area greater than $1 \mathrm{~km}^{2}$, covering a total surface area of $23700 \mathrm{~km}^{2}$, or $22.1 \%$ of China's total inland waters. The YGR in China's southwest where Karst topography is a dominant landscape has the lowest number of lakes with an area greater than $1 \mathrm{~km}^{2}$, i.e. 65 , totaling a coverage of $1399 \mathrm{~km}^{2}$ (Fig. S3). The TQR in China's west with the highest elevations has thousands of closed lakes and, the total lake area accounts more than half of China's inland waters (Ma et al., 2011). Lakes in this region are mainly fed by snow and glacier melting waters; hence, they can be sensitive to global warming (Song et al., 2016).

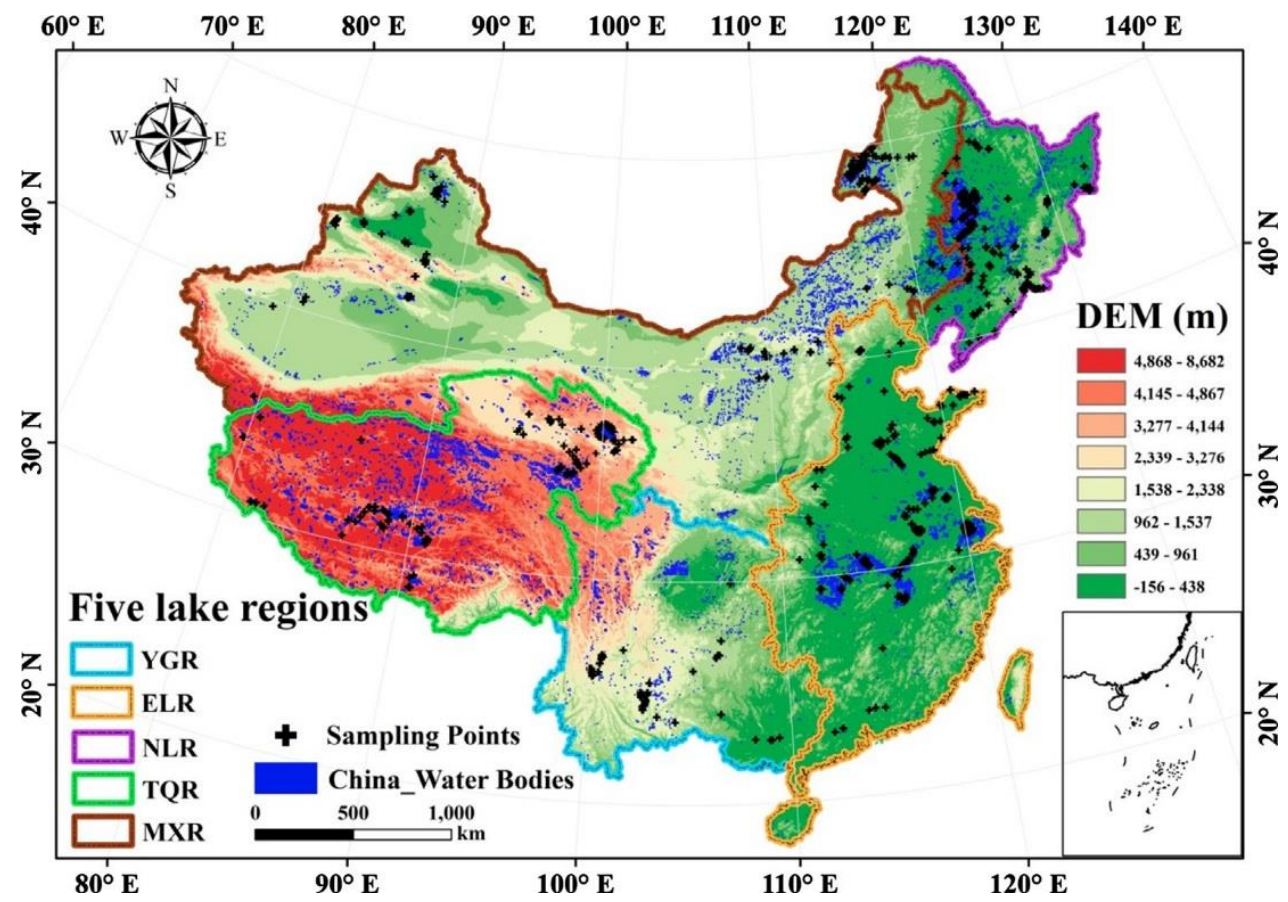

Fig. 1.

Field sampling locations from China's five limnetic regions (LR): Yungui limnetic region (YGR), East China limnetic region (ELR), Northeast China limnetic region (NLR), Tibet-Qinghai limnetic region (TQR), and Inner Mongolia-Xinjiang limnetic region(MXR). Over 1100 water samples were collected from 303 large and/or representative lakes from these regions at an elevation range from $37 \mathrm{~m}$ to $5100 \mathrm{~m}$. DEM is the abbreviation of digital elevation model.

\subsection{Water sampling and field measurements}

Multiple field campaigns were conducted every autumn from 2009 to 2015 to survey lakes distributed in China (see Fig. 1), and the field campaigns were all performed by the same research group. To be specific, 247 samples were taken from 72 lakes in the NLR in the late August 2011, September 2012, and September 2015. In the MXR, 193 samples were collected from 53 lakes in late August 2013, late September 2014, and late July-early August 2015. In total, four field surveys were carried out in September 2012, October 2014, and October 2015 in the ELR and 207 samples were collected from 49 lakes. In the YLR, two field campaigns were conducted in September 2009 and October 2015, with a total of 128 samples being collected from 25 lakes. As for the TQR, the limnetic region on the world's highest plateau, one field campaign was carried out in Qinghai Province in September 2014 and another field campaign was conducted in the Tibet Autonomous Regions in August 2015. During these two field campaigns, a total of 168 samples were collected from 50 lakes. In total, the study collected 958 water samples from 249 lakes.

Water samples were collected for laboratory chemical analysis at each of the 249 lakes we studied from approximately $0.5 \mathrm{~m}$ below the water surface, usually in the middle of the body of water. On average, 
water samples were collected at 3-4 sampling stations from every lake on average, with the samples consisting of more than $2 \mathrm{~L}$ of water, which was collected to an amber high-density polythyene (HDPE) bottle at every station. These water samples were placed in a portable refrigerator, and immediately treated with $0.2 \mathrm{~mL}$ saturated $\mathrm{HgCl} 2$ solution (final concentration, $0.02 \%$ by volume; see Dickson and Goyet, 1994) to inhibit the growth and activity of microorganisms before the samples could be got to the laboratory. All of the water samples for DC determination and analysis were filtered in situ through a $0.45 \mu \mathrm{m}$ glass-fiber filter (Bandao Industrial Co., Ltd, China). The samples were kept in the portable refrigerator at $4{ }^{\circ} \mathrm{C}$ for no more than 7 days before they were returned to a laboratory.

At all of the lakes we studied, in-situ field measurements were conducted across a number of ambient parameters, including $\mathrm{pH}$, salinity, water temperature, electrical conductivity, Secchi disk depth, total dissolved solids (TDS), and light transmission, using a YSI 600 XLM Sonde (YSI Inc., Yellow Springs, $\mathrm{OH}$ ) and a Secchi disk. This data was analyzed to determine the effect of ambient conditions on DOC and DIC concentrations. The uncertainty of measures for the $\mathrm{pH}$, salinity, and water temperature for the YSI were $0.01,0.01 \mathrm{ppt}$ and $0.001 \mathrm{~K}$, respectively.

\subsection{Water quality determination and trophic state index calculation}

Water quality parameters were measured within $24 \mathrm{~h}$ of the samples being got to the laboratory. Water samples were measured in $\mu \mathrm{S} / \mathrm{cm}$ (micro-Siemens/centimeter) units using DDS-307 electrical conductivity (EC) meter at room temperature $\left(20 \pm 2{ }^{\circ} \mathrm{C}\right)$ in the laboratory. Water turbidity was determined for the raw water samples using a Shangfen Vis-7230 spectrophotometer with a 3-cm quartz cell at room temperature $\left(20 \pm 2{ }^{\circ} \mathrm{C}\right)$, using Milli-Q water as the reference. Chlorophyll-a (Chla) was extracted from the water samples using a $90 \%$ buffered acetone solution from a $0.5 \mathrm{~L}$ water samples. The Chl-a concentration was determined using a Shimadzu UV-2660PC spectrophotometer (Shimadzu Inc., Kyoto). Water samples were filtered through $0.7 \mu \mathrm{m}$ glass fiber membranes (Whatman, GF/F 1825-047), which retained particulate matter. The membranes were pre-combusted at $450{ }^{\circ} \mathrm{C}$. Suspended particulate matter (SPM) and suspended particulate inorganic matter (SPIM) were then determined gravimetrically, as per the method, detailed in Song et al. (2013). Total nitrogen (TN) was measured according to the absorption levels in $146 \mathrm{~nm}$ of each water sample after it had been decomposed with alkaline potassium peroxydisulfate. Total phosphorus (TP) was determined using the molybdenum blue method after the samples had been digested with potassium peroxydisulfate (APHA et al., 1998). Total alkalinity (TA) was measured by titration to a desired endpoint colour using hydrochloric acid, with phenolphthalein or methyl orange being used as the indicator at room temperature $\left(20 \pm 2{ }^{\circ} \mathrm{C}\right)$. This procedure was detailed in APHA et al. (1998).

The DC was similar conducted within $24 \mathrm{~h}$ of the water being got to the laboratory. The standards for the dissolved total carbon (DTC) were prepared using reagent grade potassium hydrogen phthalate in ultrapure water. DIC levels were determined using a mixture of anhydrous sodium carbonate and sodium hydrogen carbonate (Song et al., 2013). The DOC was calculated by subtracting the DIC from the DTC, both of which were measured through high-temperature catalytic oxidation $\left(680{ }^{\circ} \mathrm{C}\right)$ using a Shimadzu Total Organic Carbon Analyzer (TOC-VCPN, Shimadzu Corporation, Japan). Analysis of blanks and replications showed a detection limit of $0.3 \mathrm{mg} / \mathrm{L}$, and a precision of $5 \%$ at a concentration of $4 \mathrm{mg} / \mathrm{L}$. All samples in the study were measured by the same instruments and the same methods. According to the Secchi disk depth, TP, and Chl-a concentrations, we evaluated the trophic state of every sampling site on the basis of a modified Carlson' s trophic state index (TSI) (Carlson, 1977; Aizaki et al., 1981). All of the sampling sites were then classified as being eutrophic, mesotrophic, or oligotrophic (262, 516, and 140 sites, respectively).

\subsection{Soil organic matter (SOM) density estimation}

In order to assess the relationship between lake DOC and soil organic matter (SOM), we derived an average SOM density from the drainage areas for 62 of the lakes. First of all, we used data from a digital elevation model (DEM) and the ArcGIS10.0 software package (Redland, Ca, USA) to delineate the drainage catchment boundaries for the lakes. The SOM data itself was derived from the second national soil census, which was conducted during 1979-1994 (Dai and Huang, 2006; Li et al., 2012). In this census, 6241 samples altogether were collected from different soil taxonomies across China (Li et al., 2012). In addition, the soil physiochemical properties, geomorphology, and types of land use were recorded at each sampling station. In our study, only the SOM percentages for the top $20 \mathrm{~cm}$ of the soils were retrieved. They were then interpolated using a Kriging algorithm in the ArcGIS10.0 software. After this, an average SOM was calculated by overlaying the catchment boundary of each lake on the interpolated SOM map. 


\subsection{Statistical analyses}

We calculated the mean DOC and DIC values for every lake, and used them to examine the DOC-DIC relationship in different limnetic regions across China. The DOC-DIC relationships for different trophic states were analyzed, drawing upon the DOC and DIC values for every samling site. For several lakes we also examined the TSI-DOC relationship. In order to provide more data for statistical analysis, we added an additional 55 groups of TSI and DOC data, that had not been included in the previous 948 samples sets, even though they had been acquired at the same sampling time.

Statistical analyses of the DC and other water quality parameters were conducted using the Matlab R2015b software package (MathWorks Inc., FL). The differences in water chemistry parameters (including DOC and DIC) for lakes in different limnetic regions across China, and the DOC/DIC ratio in fresh and brackish/saline waters were all assessed using an analysis of variance (ANOVA). In addition, a T-test was carried out to assess DOC and DIC differences between brackish and fresh water. Regression and correlation analyses were also conducted using the Origin 8.3 software package (OriginLab, Hampton, MA) to examine the relationship between DC and other water chemistry parameters. Finally, a classification regression tree approach (CHAID) was used to probe the relationship between DC concentration and nutrients in the various Chinese lakes. We used DOC or DIC concentration as the response variable and the explanatory variables were TSI, salinity, $\mathrm{pH}, \mathrm{TN}$, TP, SOM, water temperature, and suspended matter concentration. The mean value and standard errors for DOC or DIC concentration were calculated for each branch of the regression tree.

\section{Results}

\subsection{Ambient lake water conditions in different limnetic regions}

A large diversity of inland waters of varying water quality was encountered in this study. As shown in Tables 1 and 2, the waters in the ELR and NLR were extremely turbid, with a very low transparency (ELR: $0.4 \pm 0.3 \mathrm{~m}$, NLR: $0.6 \pm 0.7 \mathrm{~m}$ ). Relatively high concentrations of nutrients in most of the lakes in the ELR resulted in high concentrations of Chl-a $(52.1 \pm 252.1 \mu \mathrm{g} / \mathrm{L})$. However, most of the lakes in the NLR exhibited even higher concentrations of nutrients, most of which were derived from farmland (Fig. S3). Despite this, a relatively low Chl-a concentration was measured in this region (22.2 $\pm 39.4 \mu \mathrm{g} / \mathrm{L}$ ) because of the lower temperature (Song et al., 2013). A large variation in turbidity $(106.3 \pm 741.8 \mathrm{NTU})$ was found in the lakes in the MXR but, overall, clearer waters (SDD: $2.1 \pm 2.8$ $\mathrm{m})$ predominated in this region. Lakes in this zone also generally exhibited high concentrations of nutrients and a relatively lower concentration of Chl-a $(10.8 \pm 23.6 \mu \mathrm{g} / \mathrm{L})$. Most of the lakes in the YGR are tectonic origin, making them much deeper (average: $13.2 \mathrm{~m}$ ) and they were also more transparent (SDD: $2.2 \mathrm{~m}$ ). Lakes in the TQR are similarly of tectonic origin and of greater depth (21.7 $\pm 16.8 \mathrm{~m})$. Here, they were more transparent $(5.7 \pm 2.8 \mathrm{~m})$ due to less pollution from human activity. As this region, less populous and had limited non-point agricultural pollution, its waters contained less nutrients (TN: $0.37 \pm 0.42 \mathrm{mg} / \mathrm{L}, \mathrm{TP}: 0.04 \pm 0.05 \mathrm{mg} / \mathrm{L}$ ) and fewer forms of algal growth (Chl-a: $1.3 \pm$ $4.2 \mu \mathrm{g} / \mathrm{L})$.

In the ELR, $85 \%$ of the water bodies were eutrophic or hyper-eutrophic according to Carlson' s trophic index (Carlson, 1977). In the NLR, there was also a high percentage of water bodies were eutrophic $(67 \%)$ or mesotrophic $(33 \%)$. The percentage of eutrophic lakes was $46 \%$ and $39 \%$ respectively for the MXR and the YGR, with the remaining lakes being mesotrophic. By contrast, the alpine lakes across the Tibetan Plateau (i.e., the TQR) were all oligotrophic. As a result of the regional hydro-geological and climatic conditions, most of the waters in the NLR and MXR showed high pH values and saline waters were dominant. Through comparison (Table 2), it can be seen that lakes from the TQR $(3.8 \pm 7.0 \mathrm{psu})$ and MXR $(11.6 \pm 32.5 \mathrm{psu})$ exhibited the highest salt content, while lakes in the other three zones, particularly those in the ELR exhibited lower salt concentration and alkalinity $(100.1 \pm 38.3 \mathrm{mg} / \mathrm{L})$. 


\section{Table 1}

Field surveys for water sample collections and in-situ measurements in China's five limnological regions. Date represents sampling date; Temp denotes water temperature; EC, electric conductivity; TDS, total dissolved solid; Sal denotes salinity; Turb represents turbidity; SDD is Secchi disk depth, and Depth is the average depth of the water bodies investigated.

\begin{tabular}{|c|c|c|c|c|c|c|c|c|c|c|}
\hline $\begin{array}{l}\text { Limnetic } \\
\text { Region }\end{array}$ & Month/Year & & Temp $\left({ }^{\circ} \mathrm{C}\right)$ & $\mathrm{EC}(\mu \mathrm{S} / \mathrm{cm})$ & TDS $(\mathrm{mg} / \mathrm{L})$ & Sal $(\mathrm{mg} / \mathrm{L})$ & $\mathrm{pH}$ & Turb (NTU) & $\operatorname{SDD}(\mathrm{m})$ & Depth (m) \\
\hline East China & $8 / 2011$ & Min-Max & $13.1-28.9$ & $65.6-1389.0$ & $38.0-657.0$ & $0.0-0.6$ & $6.9-10.8$ & $2.1-495.0$ & $0.1-2.5$ & $1.1-15.9$ \\
\hline$(\mathrm{n}=207)$ & $\begin{array}{l}9 / 2012 \\
9 / 2015\end{array}$ & Mean \pm SD & $19.0 \pm 3.7$ & $383.4 \pm 303.9$ & $180.1 \pm 99.5$ & $0.1 \pm 0.1$ & $8.0 \pm 0.7$ & $58.2 \pm 65.7$ & $0.4 \pm 0.3$ & $2.8 \pm 1.8$ \\
\hline Northeast & $9 / 2011$ & Min-Max & $14.9-27.7$ & $65.8-62361.0$ & $25.0-38514.0$ & $0.0-43.4$ & $6.6-12.2$ & $0.0-4300.0$ & $0.0-4.3$ & $0.4-22.7$ \\
\hline $\begin{array}{l}\text { China } \\
(\mathrm{n}=247)\end{array}$ & $\begin{array}{l}8 / 2014 \\
9 / 2015\end{array}$ & Mean \pm SD & $22.1 \pm 3.1$ & $1403.5 \pm 4239.1$ & $948.6 \pm 3075.4$ & $0.9 \pm 3.4$ & $9.3 \pm 0.9$ & $74.7 \pm 290.8$ & $0.6 \pm 0.7$ & $3.4 \pm 4.5$ \\
\hline Inner Mongolia- & $9 / 2013$ & Min-Max & $7.9-34.2$ & $106.7-172210.0$ & $2.4-146413.0$ & $0.2-116.2$ & $7.6-13.3$ & $0.5-9555.0$ & $0.2-11.0$ & $2.1-6.8$ \\
\hline $\begin{array}{l}\text { Xinjiang } \\
(\mathrm{n}=193)\end{array}$ & $7 / 2015$ & Mean $\pm \mathrm{SD}$ & $21.5 \pm 6.0$ & $10946.8 \pm 34709.9$ & $7372.0 \pm 23538.6$ & $11.6 \pm 32.5$ & $9.2 \pm 0.8$ & $106.3 \pm 741.8$ & $2.1 \pm 2.8$ & $5.7 \pm 1.1$ \\
\hline Yungui Plateau & 9/2009 & Min-Max & $18.5-26.3$ & $115.0-1191.6$ & $173.0-731.0$ & $0.1-0.6$ & $6.9-9.3$ & $0.3-478.8$ & $0.0-7.7$ & $2.2-31.5$ \\
\hline$(\mathrm{n}=128)$ & $10 / 2015$ & Mean $\pm S D$ & $21.0 \pm 1.3$ & $474.8 \pm 303.4$ & $313.4 \pm 190.8$ & $0.3 \pm 0.2$ & $8.4 \pm 0.5$ & $27.7 \pm 63.6$ & $2.2 \pm 2.1$ & $13.2 \pm 8.4$ \\
\hline Tibetan Plateau & 9/2014 & Min-Max & $6.6-22.7$ & $120.1-67294.6$ & $148.0-43731.0$ & $0.1-50.3$ & $5.2-10.9$ & $0.0-61.6$ & $0.6-12.5$ & $3.1-102$ \\
\hline$(\mathrm{n}=168)$ & $7 / 2015$ & Mean $\pm S D$ & $12.4 \pm 3.2$ & $4359.8 \pm 8526.7$ & $3730.9 \pm 6475.7$ & $3.8 \pm 7.0$ & $8.9 \pm 0.8$ & $9.3 \pm 14.2$ & $5.7 \pm 2.8$ & $21.7 \pm 16.8$ \\
\hline
\end{tabular}

\section{Table 2}

Water quality parameter characteristics in different limnological regions of China, including total nitrogen (TN), total phosphorus (TP), total alkalinity (Alk), dissolved organic carbon (DOC), dissolved inorganic carbon (DIC), chlorophyll a (Chl-a), suspended particulate matter (SPM), suspended particulate inorganic matter (SPIM).

\begin{tabular}{|c|c|c|c|c|c|c|c|c|c|c|}
\hline Limnetic Regions & Month/Year & & $\mathrm{TN}(\mathrm{mg} / \mathrm{L})$ & $\mathrm{TP}(\mathrm{mg} / \mathrm{L})$ & Alk $(\mathrm{mg} / \mathrm{L})$ & $\operatorname{DOC}(\mathrm{mg} / \mathrm{l})$ & $\operatorname{DIC}(\mathrm{mg} / \mathrm{L})$ & Chl-a $(\mu \mathrm{g} / \mathrm{L})$ & $\operatorname{SPM}(\mathrm{m} / \mathrm{L})$ & SPIM (mg/L) \\
\hline $\begin{array}{l}\text { East China } \\
\qquad(\mathrm{n}=207)\end{array}$ & $\begin{array}{l}8 / 2011 \\
9 / 2012 \\
9 / 2015\end{array}$ & $\begin{array}{l}\text { Min-Max } \\
\text { Mean } \pm S D\end{array}$ & $\begin{array}{l}0.1-9.5 \\
0.9 \pm 1.3\end{array}$ & $\begin{array}{l}0.1-10.4 \\
0.3 \pm 1.2\end{array}$ & $\begin{array}{l}30.7-190.6 \\
100.1 \pm 38.3\end{array}$ & $\begin{array}{l}1.7-71.0 \\
6.5 \pm 6.3\end{array}$ & $\begin{array}{l}4.4-48.8 \\
20.3 \pm 9.2\end{array}$ & $\begin{array}{l}1.2-3380.5 \\
52.1 \pm 252.8\end{array}$ & $\begin{array}{l}1.7-310.0 \\
49.5 \pm 48.2\end{array}$ & $\begin{array}{l}0.2-220.0 \\
39.9 \pm 39.6\end{array}$ \\
\hline $\begin{array}{c}\text { Northeast China } \\
(\mathrm{n}=247)\end{array}$ & $\begin{array}{l}9 / 2011 \\
8 / 2014 \\
9 / 2015\end{array}$ & $\begin{array}{l}\text { Min-Max } \\
\text { Mean } \pm \mathrm{SD}\end{array}$ & $\begin{array}{l}0.1-34.2 \\
2.7 \pm 3.3\end{array}$ & $\begin{array}{l}0.1-57.2 \\
1.1 \pm 3.9\end{array}$ & $\begin{array}{l}38.4-13698.0 \\
462.5 \pm 1012.4\end{array}$ & $\begin{array}{l}3.6-790.5 \\
24.1 \pm 52.9\end{array}$ & $\begin{array}{l}8.7-2068.0 \\
95.4 \pm 179.3\end{array}$ & $\begin{array}{l}0.9-403.9 \\
22.2 \pm 39.4\end{array}$ & $\begin{array}{l}0.8-6550.0 \\
73.4 \pm 419.4\end{array}$ & $\begin{array}{l}0.1-6510.0 \\
63.7 \pm 416.2\end{array}$ \\
\hline $\begin{array}{l}\text { Inner Mongolia-Xinjiang } \\
(\mathrm{n}=193)\end{array}$ & $9 / 2013$ & $\begin{array}{l}\text { Min-Max } \\
\text { Mean } \pm \text { SD }\end{array}$ & $\begin{array}{l}0.6-26.1 \\
3.9+4.3\end{array}$ & $\begin{array}{l}0.1-6.3 \\
0.3+1.0\end{array}$ & $\begin{array}{l}48.0-2906.4 \\
444.4+3828\end{array}$ & $\begin{array}{l}3.0-300.6 \\
30 .+41.4\end{array}$ & $\begin{array}{l}10.8-543.5 \\
86.8+60.3\end{array}$ & $\begin{array}{l}0.0-152.1 \\
108+236\end{array}$ & $\begin{array}{l}0.2-14860.0 \\
127.6 \pm 1084.5\end{array}$ & $\begin{array}{l}0.0-13200.0 \\
107.9+9621\end{array}$ \\
\hline Yungui Plateau & $\begin{array}{l}9 / 2009 \\
9 / 2009\end{array}$ & Min-Max & $\begin{array}{l}3.9-4.3 \\
0.2-15.6\end{array}$ & $0.01-6.8$ & $\begin{array}{l}86.4-801.6 \\
80.6\end{array}$ & $\begin{array}{l}3.4-20.8 \\
1.4\end{array}$ & $\begin{array}{l}3.8-20.3 \\
13.2-179.7\end{array}$ & $0.6-1256.2$ & $0.1-310.0$ & $0.0-70.0$ \\
\hline $\begin{array}{l}(\mathrm{n}=128) \\
\end{array}$ & $10 / 2015$ & Mean $\pm \mathrm{SD}$ & $5.5 \pm 4.4$ & $0.1 \pm 0.8$ & $231.6 \pm 204.6$ & $7.0 \pm 4.9$ & $51.6 \pm 48.9$ & $104.1 \pm 213.6$ & $22.3 \pm 47.0$ & $6.0 \pm 11.5$ \\
\hline Thetan Plateau & 9/2014 & Min-Max & $0.1-2.9$ & $0.02-0.2$ & $95.5-15834.0$ & $0.3-151.3$ & $2.0-3472.0$ & $0.01-32.6$ & $0.01-45.8$ & $0.0-39.3$ \\
\hline$(\mathrm{n}=168)$ & $7 / 2015$ & Mean $\pm S D$ & $0.9 \pm 0.7$ & $0.1 \pm 0.01$ & $1804.3 \pm 3081.1$ & $13.4 \pm 19.3$ & $222.8 \pm 469.0$ & $1.3 \pm 4.2$ & $7.6 \pm 10.9$ & $5.9 \pm 8.5$ \\
\hline
\end{tabular}

\subsection{Spatial distribution of DOC concentration in China' $s$ lakes}

As shown in Figs. 2a and 3a, lakes in the NLR exhibited the highest DOC concentration, followed by the MXR, TQR, and YGR. Water bodies situated in the ELR displayed the lowest DOC concentration overall. It can be seen from Table 2 that the DOC concentrations in lakes in the ELR ranged from 1.7 $\mathrm{mg} / \mathrm{L}$ in Dongting Lake to $71.0 \mathrm{mg} / \mathrm{L}$ in Xiashan Lake. A low average DOC concentration was recorded here $(6.5 \mathrm{mg} / \mathrm{L})$ with some moderate variation (S.D., $6.3 \mathrm{mg} / \mathrm{L})$. However, the median value in this Limnetic Region was much lower $(3.6 \mathrm{mg} / \mathrm{L})$. The average DOC concentration in the ELR was significantly different from those in the NLR $(\mathrm{F}=232.4, \mathrm{p}<0.001)$, MXR $(\mathrm{F}=232.4, \mathrm{p}<0.001)$, TQR $(\mathrm{F}=132.5, \mathrm{p}<0.001)$, and YGR $(\mathrm{F}=32.4, \mathrm{p}<0.01)$. Compared to the ELR, waters in the NLR demonstrated notably higher DOC concentrations $(24.1 \mathrm{mg} / \mathrm{L})$ with a large variation $(3.6-790.5 \mathrm{mg} / \mathrm{L})$ and a large standard deviations $(52.9 \mathrm{mg} / \mathrm{L})$. DOC concentration in the NLR was also significantly different to that of the YGR $(F=207.6, p<0.001)$ and the TQR $(F=134.2, p<0.001)$. Like the NLR, lakes in the MXR also exhibited a high average DOC concentration and a large variations $(30.1 \pm 41.4$ $\mathrm{mg} / \mathrm{L})$, which is noticeably different again from the YGR $(\mathrm{F}=175.3, \mathrm{p}<0.001)$ and the TQR $(\mathrm{F}=57.6$, $\mathrm{p}<0.01)$. It turned out that terminal waters in the MXR exhibited higher DOC concentrations $(16.4 \pm$ $7.4 \mathrm{mg} / \mathrm{L})$ than open waters $(5.6 \pm 2.4 \mathrm{mg} / \mathrm{L})$, and significant difference was observed between these two water types $(\mathrm{F}=232.4, \mathrm{p}<0.0001$, see Fig. 2). As for lakes in the YGR, a comparable average DOC concentration $(7.0 \pm 4.9 \mathrm{mg} / \mathrm{L})$ was measured to that of the ELR, where fresh water bodies prevail in the outflow region. A large range of DOC concentration (0.3-151.3) was encountered for the lakes situated in the TQR, with a relatively high average concentration of DOC $(13.4 \mathrm{mg} / \mathrm{L})$. 

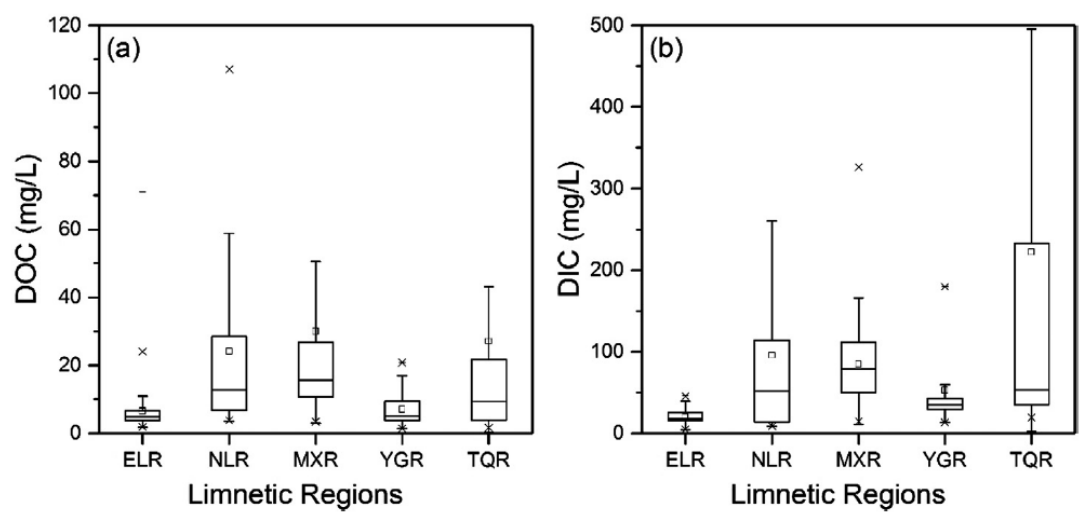

\section{Fig.2.}

Box and whisker plots showing median, minimum, maximum, and the upper and lower quartiles of dissolved organic carbon, (a) and dissolved inorganic carbon (b) concentrations in lake waters from five different limnetic regions across China. Large variability has been found in DIC concentration, especially in high-latitude (NLR) or high-altitude (TQR) cold regions.

\subsection{Spatial distribution of DIC concentration in China' s lakes}

Equally large variations in DIC concentration were observed across the waters of the different limnetic regions (Table 2, Fig. 2b, Fig. 3b), with both minimum $(2.0 \mathrm{mg} / \mathrm{L})$ and maximum $(3472.0 \mathrm{mg} / \mathrm{L})$ values being recorded in the lakes of the Tibetan Plateau. As can be seen in Fig. 2b, the lowest average (20.3 \pm $9.2 \mathrm{mg} / \mathrm{L})$ DIC was displayed in the ELR, and it was significantly different from that in the NLR $(\mathrm{F}=29.8, \mathrm{p}<0.01), \mathrm{MXR}(\mathrm{F}=176.4, \mathrm{p}<0.0001)$, YGR $(\mathrm{F}=65.9, \mathrm{p}<0.001)$, and TQR $(\mathrm{F}=31.5, \mathrm{p}<$ $0.001)$. The DIC concentration in the waters of the NLR had the highest mean value $(95.4 \mathrm{mg} / \mathrm{L})$ with a large variation (range: $8.7 \sim 2068.7 \mathrm{mg} / \mathrm{L} ; \mathrm{S} . \mathrm{D}=179.3 \mathrm{mg} / \mathrm{L}$ ). This was significantly different again from the YGR $(\mathrm{F}=5.3, \mathrm{p}<0.05)$ and the TQR $(\mathrm{F}=11.01, \mathrm{p}<0.01)$. It was not significantly different, however, from the MXR $(\mathrm{F}=0.5, \mathrm{p}=0.45)$. Further examination revealed that extremely high DIC concentrations were to be found in brackish waters (203.5 $\pm 110.4 \mathrm{mg} / \mathrm{L})$ (Figs. 2b and S1), with a much higher average value than that reported by Duarte et al. (2008). Generally, a significant difference for DIC was observed between brackish and fresh waters ( $p<0.0001)$. Likewise, high DIC concentrations were observed for waters situated in semi-arid or endorheic regions, i.e. the MXR and the TQR (Table 2, Figs. 2b and 3b). Another feature to be noted from Fig. 2 is that both DOC and DIC demonstrated stable trends for waters, except for the waters in the TQR, where extremely high DIC concentrations were found. Similarly, the DIC concentrations in the MXR were significantly different from those of the YGR $(\mathrm{F}=19.8, \mathrm{p}<0.001)$ and TQR $(\mathrm{F}=15.7, \mathrm{p}<0.001)$, with these last two regions also being significantly different from one another $(\mathrm{F}=12.2, \mathrm{p}<0.01)$. 

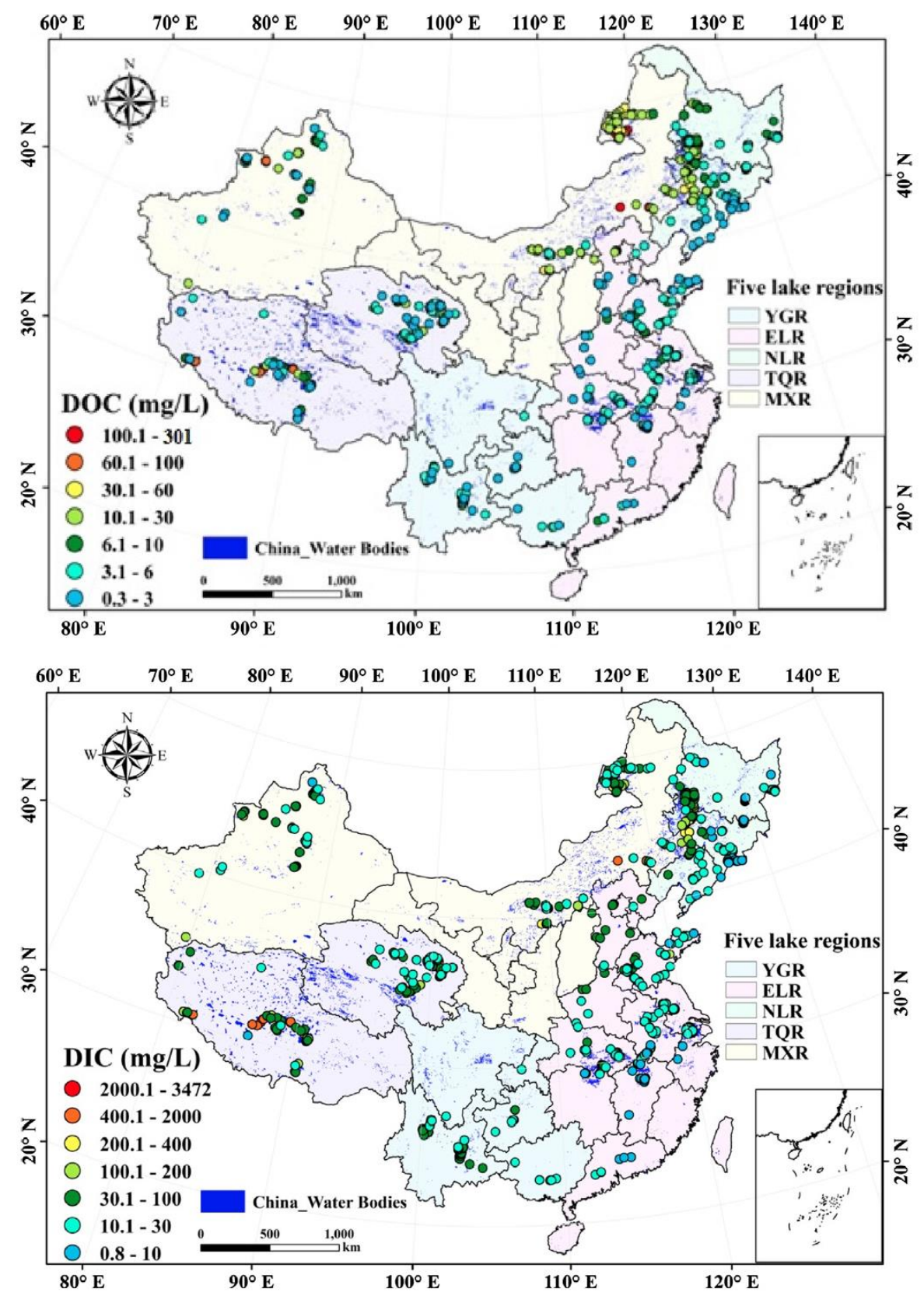

\section{Fig. 3.}

Spatial distributions of dissolved organic carbon (above) and dissolved inorganic carbon (below) concentrations in lake waters from five different limnetic regions across China. High DOC levels were found mainly in drier climate, while extremely high DIC levels were found in brackish and saline lakes on the Qinghai-Tibet Plateau.

\subsection{Relationship between DOC and DIC}

This study found no consistent relationship between DOC and DIC across China' s five limnetic regions (Fig. 4), but it did find a significantly higher DOC/DIC ratio $(0.33 \pm 0.13)$ in freshwater lakes than in brackish/saline waters $(0.21 \pm 0.14)(p<0.01)$. In the ELR, a linear increasing trend can be seen for this, with a high scatter (Fig. 4a). In the NLR, there was a closer relationship between DOC and DIC (Fig. 4b, $R_{2}=0.72$ ). Though not as close as in the NLR, we also found a positive link between DOC and DIC in the lakes of the MXR (Fig. 4c, $\mathrm{R}_{2}=0.41$ ) and the TQR (Fig. 4e, $\mathrm{R}_{2}=0.62$ ). In the most extreme case, however, there was no visible relationship between DOC and DIC at all for the lake waters in the YGR (Fig. 4d). 
In this study, we found a close relationship between DOC and DIC under trophic states: an $\mathrm{R}_{2}$ of 0.69 for eutrophic, 0.65 for mesotrophic, and 0.64 for oligotrophic (Fig. 5). Interestingly, the regression slopes varied according to trophic state, $0.63,1.03$, and 1.00 for eutrophic, mesotrophic and oligotrophic water bodies respectively. In the eutrophic water bodies, the DIC was only slightly higher than the DOC in the water column, but in the mesotrophic and oligotrophic water bodies, the DIC was respectively 6.5 and 19.5 times the DOC. We compared the DOC and DIC concentrations in different trophic states, and found that eutrophic water bodies showed the highest mean and median DOC concentration, but the lowest mean DIC concentration. The oligotrophic water bodies, by contrast, showed the highest mean DIC concentration.
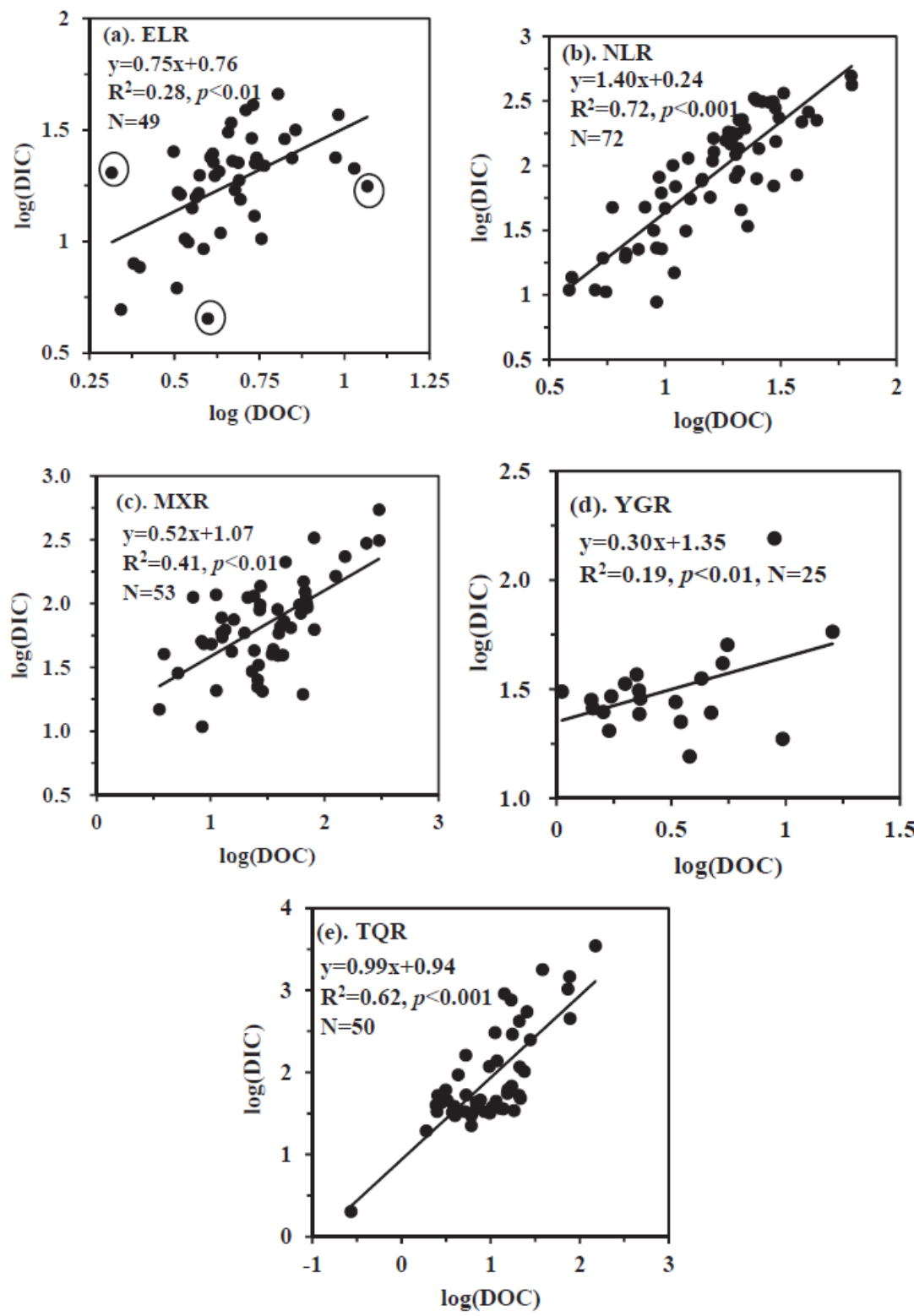

Fig.4.

Different relationships between DOC and DIC concentrations in lake waters from five different limnetic regions of China:(a) East China limnetic region (ELR), (b) Northeast China limnetic region (NLR), (c) Inner Mongolia-Xinjiang limnetic region (MXR), (d) Yungui limnetic region (YGR),(e) Tibet-Qinghai limnetic region (TQR). 

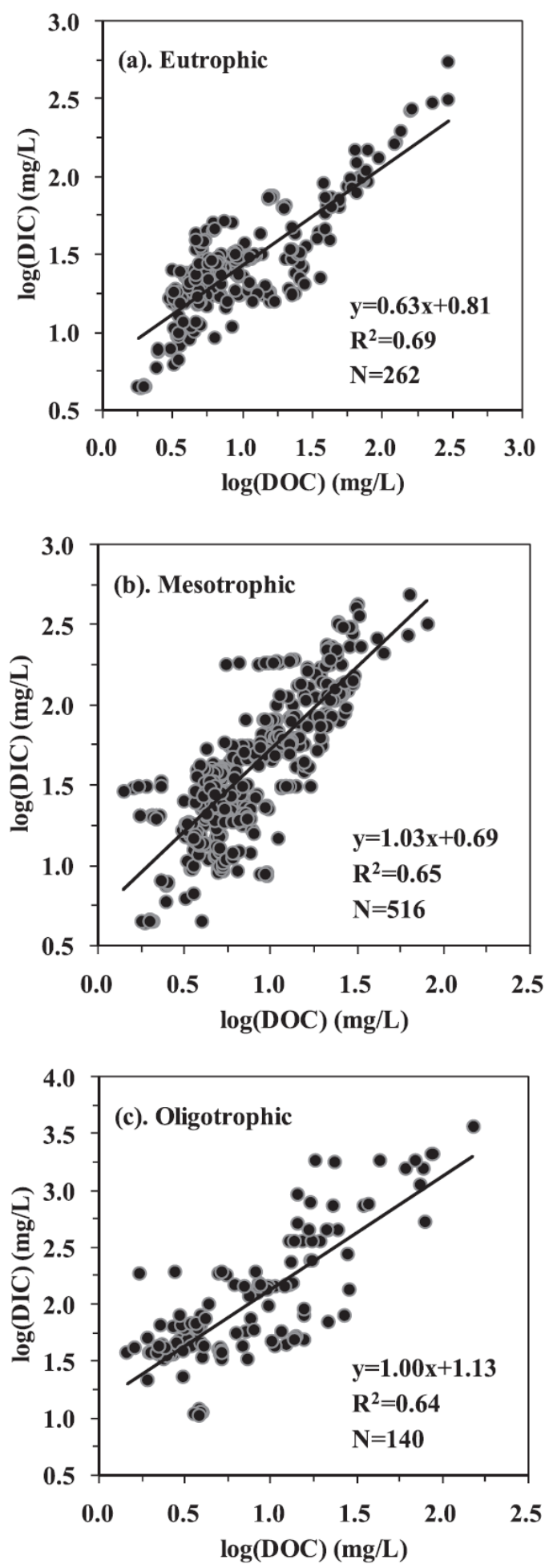

Fig.5.

Relationships between DOC and DIC concentrations in lake waters across China under different trophic state: (a) eutrophic water bodies, (b) mesotrophic water bodies, and (c) oligotrophic water bodies. 


\subsection{Relationship between DOC and environmental factors}

The regression tree analysis of the DC content in these waters showed it to be mainly influenced by the trophic states, salinity of the water, and SOM. The relationship between DOC and the trophic states of the lakes in the NLR shown in Fig. 6a $\left(\mathrm{R}_{2}=0.65\right)$. It can be seen that cleanest water in Songhua Lake exhibited a low DOC concentration with a very low Chl-a concentration. The most eutrophic lake, i.e. Lamasi Lake, showed high concentrations of DOC and Chl-a (Table S1). As shown in Fig. 6b, there was a close association $\left(\mathrm{R}_{2}=0.59\right)$ between DOC and TSI in the six representative lakes from the ELR (also see Fig. S4 and Table S1). In the case of the YGR, six lakes with gradient eutrophic states were also selected to explore the relationship between DOC and TSI more closely (see Fig. 6c). It can be seen that the oligotrophic lake, Fuxian exhibited the lowest DOC and Chl-a concentrations (Table 2). The extremely eutrophic ones (Tables 2, and S1), Dianchi and Xingyun Lake, however, showed higher DOC and Chl-a concentrations. Thus, a close relationship between TSI and DOC was revealed for the lakes in the YGR $\left(\mathrm{R}_{2}=0.78\right)$.

We also found a significant relationship between the DOC in lake waters and the SOM density in the drainage catchments (Fig. 7b; $\mathrm{R}_{2}=0.45$ ). Lakes in the ELR and TQR exhibited low DOC in the lakes and a low SOM density in the corresponding catchments (Fig. 7a). Meanwhile, a high SOM density was found in the NLR, which corresponded with high DOC concentration in lakes. The relationship between DC and salinity is presented in Fig. 8. It can be seen that the slope and intercept for DOC and salinity in the regression model is distinct from the result for DIC (Fig. 8a and b). Note, in this respect, that a significant difference was observed for DOC between the lakes in the exorheic and endorheic regions $(\mathrm{F}=148.6, \mathrm{p}<0.001)$, but an even more remarkable difference was exhibited for DIC across these two different hydrological units $(\mathrm{F}=236.3$, $\mathrm{p}<0.001)$. For both DOC and DIC, the concentrations in the endorheic region were higher than in exorheic region. 

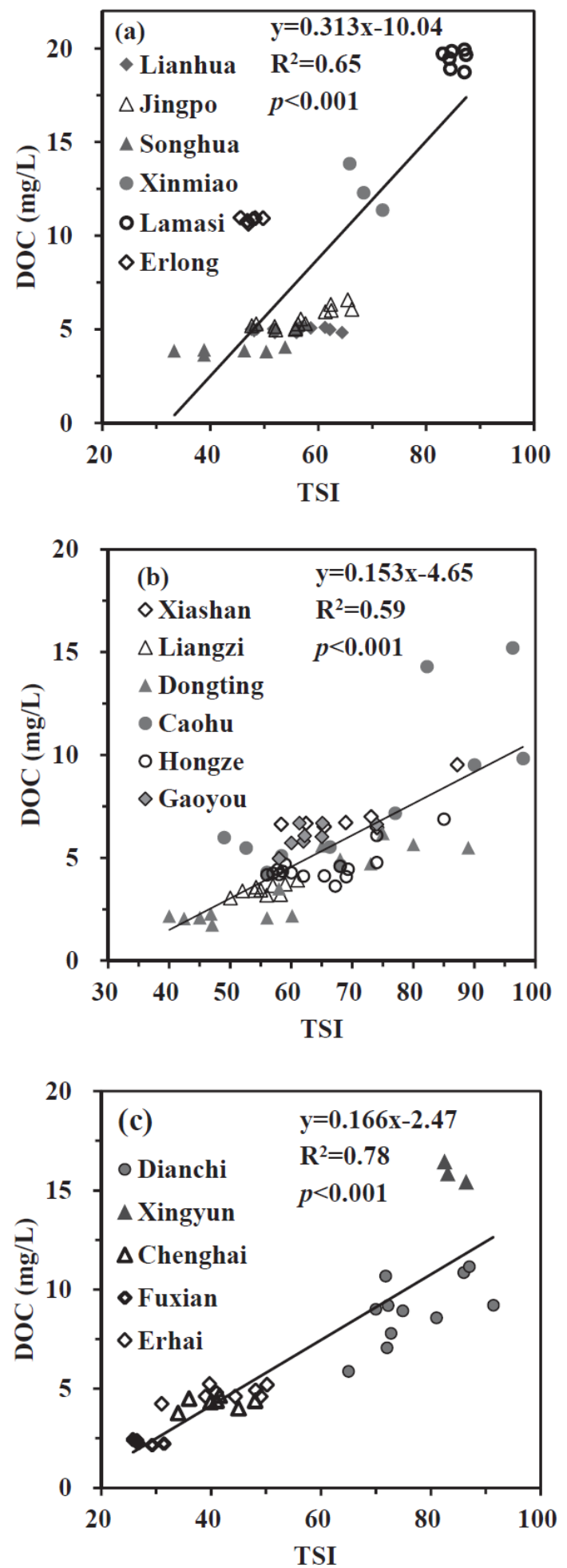

\section{Fig.6.}

Impact of trophic state on the concentration of DOC in fresh water limnetic regions to avoid the impact of accumulated effect in brackish waters, (a) the Northeast limnetic region, (b) the East China limnetic region, and (c) the Yungui limnetic region. 

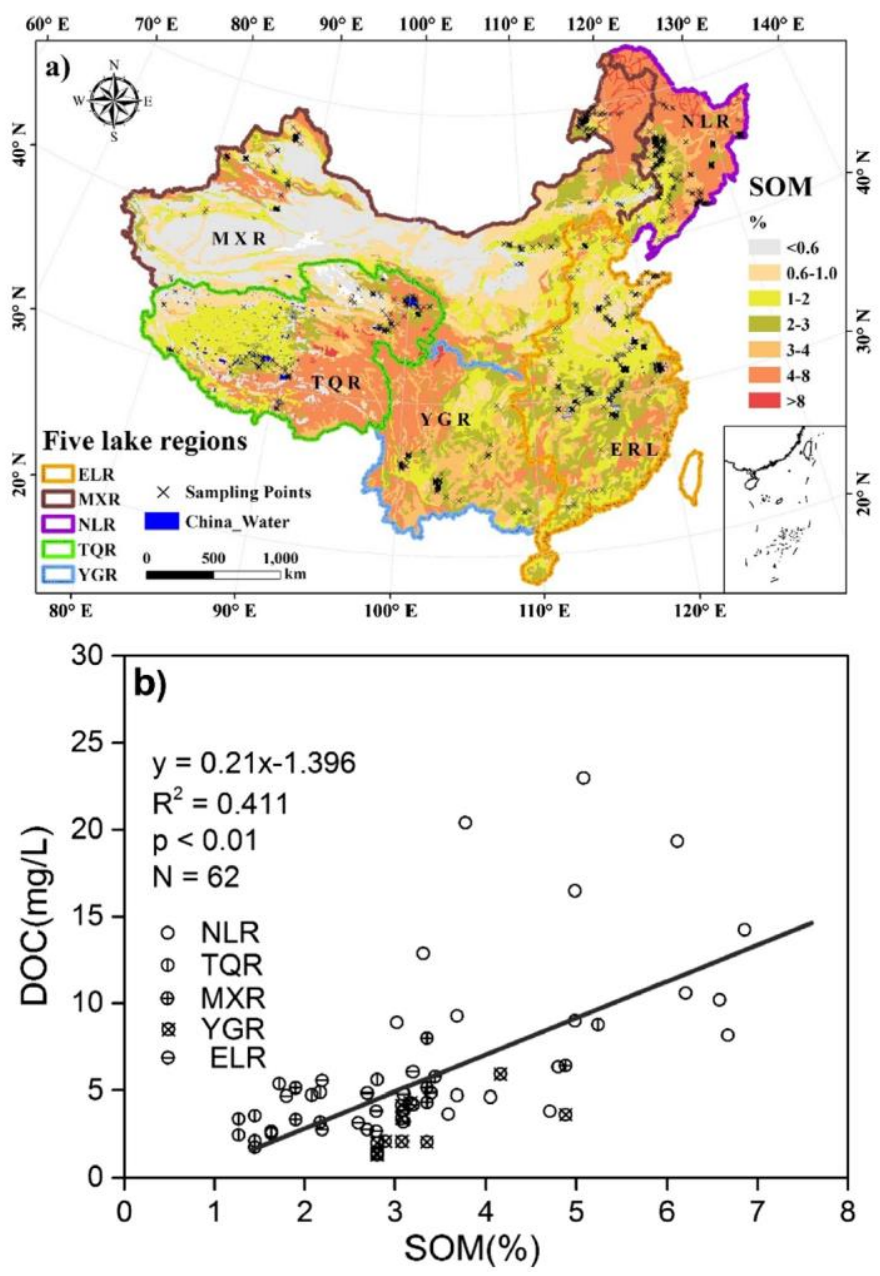

Fig.7.

Soil organic matter (SOM) contents in five limnetic regions of China (a), and the relationship between SOM and DOC concentration in lake waters. China's most northern region, NLR, has the highest SOM and lake waters in the region show the closest DOC-SOM relation.

\section{Discussion}

\subsection{Analysis of the dissolved carbon in Chinese lakes}

We conducted a large-scale assessment of the DOC and DIC in 249 lakes in five Chinese limnetic regions. We have also examined the relationship between DOC and DIC in these lake waters according to their different trophic states and the different limnetic regions. The relationship between DOC and DIC in the ELR produced a high degree of scatter (Fig. 4a). When the samples from the ELR were further analyzed, the results showed that some of the lakes were severely impacted along a linear trend. Examples here include Lake Chaohu, Chenjia Lake and Dongting Lake, which are circled in Fig. 4a. Algal bloom combined with sediment re-suspension caused by strong winds may explain the biased relationship between DOC and DIC in these lakes, as it was found previously by Xu et al. (2017). However, when the samples in the circle in Fig. 4a were excluded, the linear trend remained signif icant $\left(\mathrm{R}_{2}=0.42\right)$. In the NLR, MXR, and TQR, a close relationship between DOC and DIC was revealed (Fig. 4b, b, and e), indicating that both forms of dissolved carbon were largely originating from the same source. Weyhenmeyer et al. (2015) have reported that DIC inputs to lakes generally come from their drainage basin, rather than being produced within the lakes themselves. So, for locations in the northern temperate climatic zone, DOC and DIC are mainly originating from external sources, and a close relationship between them would seem to hold. The lake of relationship between DOC and DIC in the YGR lake waters suggests that, in this case, the DOC and DIC are probably being derived from different sources, as will be explained in the following section (Fig. 4d). 
Furthermore, the different relationships between DOC and DIC in the different limnetic regions (Fig. 4) may be a result of the lakes having different catchment geologies. The dominant sources for DIC in waters can be either terrestrial or through aquatic ecosystems (Wetzel, 2001; Weyhenmeyer et al., 2015). The Yungui Plateau consists of two distinct regions: a high alpine region in Northwestern Yunnan Province, and a region endowed with rolling karst hills in the northern Yunnan and western Guizhou provinces. As most of the catchments are sitting on karst (Fig. S3), and there is abundant precipitation, the production of carbonic acid prevails is one of the primary reactions. According to our results, lakes in China' s five limnetic regions outside of those located in areas of karst regions, show a close relationship between DOC and DIC (Fig. 4b, c, e). It is possible that limestone rocks may be limited as a source of DIC in the case of both surface and/or ground water. The dissolution of carbonate rocks absorbs large amounts of atmospheric $\mathrm{CO}_{2}$ every year (Shen et al., 2017). Carbonate weathering in the watershed would supply more DIC to the surface water (Marce et al., 2015). This being to, further studies are needed to elucidate the DOC-DIC relationship in lakes situated in karst landscapes.

\subsection{Effect of the trophic state on lake DOC and DIC}

In this study, we found that eutrophic water bodies showed the highest mean and median DOC concentration, but the lowest mean DIC concentration when compared to meso- and oligotrophic waters. Many studies have shown that eutrophic waters tend to have higher DOC concentrations or a higher DOC light absorption coefficient than mesoand oligotrophic waters (Sugiyama et al. 2004; Williamson et al. 1999; Yoshioka et al. 2002; Zhang et al., 2018), The primary explanation for this is that, during phytoplankton blooms, the phytoplankton cell burst is contributing carbohydrates to autochthonous DOC (Findlay and Sinsabaugh, 2003; Finlay et al., 2010; Roland et al., 2010; Ye et al. 2010; Pacheco et al., 2013; Ye et al. 2015). Eutrophic waters always have higher photosynthetic rates than meso- and oligotrophic waters because of algal blooms. It is possible that these may be consuming more carbon dioxide during the photosynthesis process, resulting in a lower DIC concentration in lakes. It will be remembered that, when we looked at the DOC -DIC regression slopes, we found that DIC was signif icantly higher than DOC in oligotrophic waters. This was mainly due to the fact that these samples were collected in saline waters that are situated in the endorheic regions of the TQR and MXR. DIC accumulates much faster than DOC from the catchment here, so a much higher DIC was exhibited. However, DIC was only slightly higher than DOC in the water column in eutrophic waters and it had a lower slope value compared to meso- and oligotrophic waters. This may be related to the autochthonous DOC in eutrophic waters, which is highly bioreactive in the carbon cycle (Kalinowska 2004; Ye et al. 2010).

Through inspection of the DOC concentration across different eutrophic state in different limnetic regions, it was found that highly eutrophic lakes generally demonstrated higher DOC concentration than other lakes situated nearby that are less eutrophic. Saline lakes located in endorheic regions generally exhibit high DOC concentrations (Curtis and Adams, 1995; Song et al., 2013; Wen et al., 2016). We therefore only examined lakes in the ELR, NLR, and YGR outflow regions to explore the relationship between DOC concentrations and lake trophic states (see Fig. S4 for their locations). Although, we cannot guarantee that the high DOC concentration in these eutrophic lakes originated directly from algae released carbon or byproducts, the strong association between TSI and DOC (Fig. 6) strongly implies that eutrophication has altered the DOC sources and its natural carbon density. This has also been found in other studies (Finlay et al., 2010; Pacheco et al., 2013; Zhou et al., 2015).

Nutrients from intensive agricultural practice and densely populated urban areas (Figs. S1 and S4), combined with industrial discharge, have caused serious eutrophication in most of the lakes in the ELR (MEPC, 2015; Zhou et al., 2017). Thus, a similar pattern was tracked across the lakes in this region, with the Dongting Lake showing a low DOC concentration that is connected to the Yangzi River, while the Chaohu Lake, where algal bloom is frequently observed (Yang et al., 2013; Xu et al., 2016), exhibited a high DOC concentration. A close relationship between TSI and DOC was revealed across the representative lakes from the ELR and YGR (Fig. 6). This indicates that eutrophication exerts an important influence upon DOC concentration in lake waters. This has also been confirmed by other investigations (Finlay et al., 2010; Pacheco et al., 2013; Zhou et al., 2016). It should be noted that the high DOC concentration in these eutrophic lakes may partly originate from the discharge of industrial or domestic sewage or from industrial effluent waters, coupled together with the DOC originating from algal bloom (Zhou et al., 2017). Further investigation is needed to identify and separate the DOC that is derived from algal bloom, for instance by using isotope tracers or other biomarkers (Urban et al., 2005; Kellerman et al., 2015; Zhou et al., 2016), so that the algal bloom contribution to DOC can be quantitatively assessed. 


\subsection{Influencing of environmental factors on lake DOC}

A significant relationship between DOC in lake waters and SOM density in the drainage catchments was found in this study (Fig. 7). Previous studies (e.g., Agren et al., 2007; Philips, 2010) have reported a connection between the level of DOC in lakes and SOM density in catchment areas and have suggested that this is because DOC in aquatic systems is mainly derived from allochthonous sources. Studies have also found that the DOC level in lake water is often reflected in the watershed soil C:N ratio, its carbon density, the percentage of wetlands, the watershed size, and the hydrologic conditions (Spencer et al., 2012). In this study, we have looked at 249 lakes that are the receiving water bodies for drainage basins with vastly different SOM densities. To exclude the impact of autochthonous DOC from algal bloom and the direct input of DOC from human activity through wastewater discharge, we have specifically examined freshwater lakes with low Chl-a, TN, and TP concentrations for each limnetic region (i.e. oligotrophic or mesotrophic lakes with low TSI values). There is no doubt that climatic, hydrological conditions and land use/cover are also having an influence on the DOC concentration in lake waters (Sobek et al., 2007; Wilson et al., 2009; Catalan et al., 2016). So, the relationship between DOC concentration and catchment SOM density may start to appear less correlated over time.

Inspection of the water samples indicated that waters with high DOC concentrations were located in the endorheic regions of the western Songnen Plain (Song et al., 2013; Zhao et al., 2016). The

signif icantly higher DOC and DIC levels found in the endorheic lakes in our study may be mainly the result of a cumulative effect. Within semi-humid and semi-arid regions, endorheic lakes predominant (Fig. S3), so the chemical substances in the water accumulate because of the condensing effect of surface evaporation. This being the case, dissolved carbon accumulated incrementally along with the salinity or TDS, depending on the water duration times and the accumulation of dissolved matter (Duarte et al., 2008; Mattsson et al., 2009; Catalan et al., 2016). This relationship implies that source and sink patterns are similar amongst lakes in semi-arid or arid regions. The most likely explanation is that the most persistent DOC after photo- and bio-degradation has taken place is evapo-concentrated in these semi-arid or arid regions, and the accumulated carbon is then stored in these closed inland waters. In comparison, DIC is more stable than DOC, which explains the stable relationship between DIC and salinity (Song et al., 2013). Long periods of exposure to sunlight may also be enhancing photochemical oxidation processes in these saline waters and causing higher DIC concentration (Brooks and Lemon, 2007; Tobias and Bohlke, 2011). Land use may also be playing an important role, with the salinealkaline soil around these water bodies contributing significantly to DIC concentration through erosion and surface runoff (Duarte et al., 2008; Song et al., 2013; Wetzel, 2001; Wilson and Xenopoulos, 2008). An empirical model could be calibrated using a larger dataset to estimate DIC for inland waters in semi-arid or arid regions. DOC, however, is more labile (subject to photochemical and microbial degradation) and has a wider variety of sources (allochthonous, autochthonous, and anthropogenic discharge) and composition (Spencer et al., 2012). This results in a different relationship between DOC and salinity. Nonetheless, with properly calibrated models and data sets collected across various seasons, it should also be possible to estimate the DOC concentration for semiarid or arid zones and thus explain its the high variance $\left(R_{2}>0.6\right)$.

\section{Conclusions}

This study is the first landscape-level assessment of dissolved organic and dissolved inorganic carbon in lake waters to be undertaken across the whole of China, covering different climatic, geopedological, topographical, and limnological conditions. Based on the findings, the following conclusions can be drawn:

(1) SOM density and catchments in the landscape exert a strong influence uopn the levels of DOC and DIC in China' $s$ inland waters and this is the major driving factor for the high levels of DOC and DIC in lakes in the NLR.

(2) Salinity plays an important role in affecting the DOC and DIC levels in lake water, with the DOC and DIC concentrations in fresh water lakes in the ELR, YGR and parts of the NLR being much lower than they are in the brackish/saline (terminal) waters in the TPR and MXR. This is most probably due to the condensing effect of surface evaporation, leading to the possibility of predicting dissolved carbon and salinity in brackish or saline waters in endorheic regions.

(3) Eutrophication caused by human activity can increase DOC levels, particularly where this promotes 
excess growth of algae and organic accumulation.

(4) Our initial hypothesis that the relationship between DOC and DIC is changing in tandem with environmental change is proven. A close and positive relationship between DOC and DIC in lake waters was only found in non-carbonate dominated regions, suggesting that karst landscapes may deviate from the broader trend.

\section{Acknowledgements}

This research was jointly supported by the Foundation of China' s High Resolution Earth Observation (No. 41-Y20A31-9003-15/17), the National Natural Science Foundation of China (No. 41730104, No. 41501387), the "One Hundred Talents" program from Chinese Academy of Sciences granted to Dr. Kaishan Song, and Jilin Scientific \& Technological Development Program (No. 20160520075JH). The authors wish to thank graduate students Sijia Li, Ming Wang, Junbin Hou and Linwei Sha for their capable assistance in the field sampling and laboratory measurements.

\section{References}

Agren, A., Buffam, I., Jansson, M., Laudon, H., 2007. Importance of seasonality and small streams for the landscape regulation of dissolved organic carbon export. J. Geophys. Res. 112, G03003.

Aizaki, M., Otsuki, A., Fukushima, T., Kawai, T., Hosomi, M., Muraoka, K., 1981. Application of modified Carlson's trophic state index to Japanese lakes and its relationship to other parameters related to trophic state, pp. 13-31, Tuskuba, Japan. APHA/AWWA/WEF, 1998. Standard Methods for the Examination of Water and Wastewater. American Public Health Association, Washington, DC. Armstrong, N., 2010. Lake carbon. Nat. Geosci. 3, 151.

Arts, M.T., Robarts, R.D., Kasai, F., Waiser, M.J., Tumber, V.P., Plante, A.J., Rai, H., de Lange, H.J., 2000. The attenuation of ultraviolet radiation in high dissolved organic carbon waters of wetlands and lakes on the northern Great Plains. Limnol. Oceanogr. 45 (2), 292-299.

Borges, A.V., Darchambeau, F., Teodoru, C.R., Marwick, T.R., Tamooh, F., Geeraert, N., Omengo, F.O., Guerin, F., Lambert, T., Morana, C., Okuku, E., Bouillon, S., 2015. Globally significant greenhouse-gas emissions from African inland waters. Nat. Geosci. http://dx.doi.org/10.1038/NGEO2486.

Brooks, P.D., Lemon, M.M., 2007. Spatial variability in dissolved organic matter and inorganic nitrogen concentration in a semiarid stream, San Pedro River, Arizona. J. Geophys. Res. 112, G03S05.

Butman, D.E., Wilson, H.F., Barnes, R.T., Xenopoulos, M.A., Raymond, P.A., 2015. Increased mobilization of aged carbon to rivers by human disturbance. Nat. Geosci. 8 (2), 112-116.

Carlson, R.E., 1977. A trophic state index for lakes. Limnol. Oceanogr. 22 (2), 361-369. Catalan, N., Marce, R., Kothawala, D.N., Tranvik, L.J., 2016. Organic carbon decomposition rates controlled by water retention time across inland waters. Nat. Geosci. 9 (7), 501.

Cole, J.J., Caraco, N.F., Kling, G.W., Kratz, T.K., 1994. Carbon dioxide supersaturation in the surface of lakes. Science 265, 1568-1570.

Cole, J.J., Prairie, Y.T., Caraco, N.F., McDowell, W.H., Tranvik, L.J., Striegl, R.G., Duarte, C.M., Kortelainen, P., Downing, J.A., Middelburg, J.J., Melack, J., 2007. Plumbing the global carbon cycle: integrating inland waters into the terrestrial carbon budget. Ecosystems 10, 171-184.

Cory, N., Buffam, I., Laudon, H., Kohler, S., Bishop, K., 2006. Landscape control of stream water aluminum in a boreal catchment during spring flood. Environ. Sci. Technol. 40 (11), 3494-3500.

Curtis, P.J., Adams, H.E., 1995. Dissolved organic matter quantity and quality from freshwater and saltwater lakes in east-central Alberta. Biogeochemistry 30 (1), 59-76.

Dai, W.H., Huang, Y., 2006. Relation of soil organic matter concentration to climate and altitude in zonal soils of China. Catena 65 (1), 87-94. 
Dickson, A.G., Goyet C., 1994. U.S. Department of Energy (DOE). Handbook of methods for the analysis of the various parameters of the carbon dioxide system in sea water, v. 2. ORNL/CDIAC-74. Available from http://cdiac.esd.ornl.gov/oceans/DOE_94.pdf.

Duarte, C.M., Prairie, Y.T., Montes, C., Cole, J.J., Striegl, R.G., Melack, J., Downing, J.A., 2008. $\mathrm{CO}_{2}$ emission from saline lakes: a global estimates of a surprisingly large flux. J.

Geophys. Res. 113, G04041.

Findlay, S., Sinsabaugh, R.L., 2003. Aquatic Ecosystems Interactivity of Dissolved Organic Matter. Academic press, Elsevier Science USA.

Finlay, K., Leavitt, P.R., Patoine, A., Wissel, B., 2010. Magnitudes and controls of organic and inorganic carbon flux through a chain of hard-water lakes on the northern Great Plains. Limnol. Oceanogr. 55 (4), 1551-1564.

Gudasz, C., Bastviken, D., Steger, K., Premke, K., Sobek, S., Tranvik, L.J., 2010.

Temperature-controlled organic carbon mineralization in lake sediments. Nature 466, 478-481.

Hanson, P.C., Hamilton, David P., Stanley, Emily H., Preston, Nicholas, Langman, Owen C., Kara, Emily L., 2011. Fate of allochthonous dissolved organic carbon in lakes: a quantitative approach. PLosOne. http://dx.doi.org/10.1371/journal.pone.0021884. Kalinowska, K., 2004. Bacteria, nanoflagellates and ciliates as components of the microbial loop in three lakes of different trophic status. Polish J. Ecol. 52, 19-34.

Karlsson, J., Bystrom, P., Ask, J., Ask, P., Persson, L., Jasson, M., 2009. Light limitation of nutrient-poor lake ecosystems. Nature 460, 506-509.

Kawasaki, N., Komatsu, K., Kohzu, A., Tomioka, N., Shinohara, R., Satou, T., Watanabe, N., Tada, Y., Hamasaki, K., Kushairi, M., Imaia, A., 2013. Bacterial contribution to dissolved organic matter in eutrophic lake Kasumigaura, Japan. Appl. Environ.

Microbiol. 79, 7160-7168.

Kellerman, A.M., Kothawala, D.N., Dittmar, T., Tranvik, L.J., 2015. Persistence of dissolved organic matter in lakes related to its molecular characteristics. Nat. Geosci. 8 (6) 454-U52.

Li, Q.Q., Wang, C.Q., Yue, T.X., Zhang, W.J., Yu, Y., 2012. Method for spatial simulation of topsoil organic matter in China based on a neural network model. Adv. Earth Sci. 27 (2), 175-184.

Ma, R., Yang, G., Duan, H., Jiang, J., Wang, S., Feng, X., Li, A., Kong, F., Xue, B., Wu, J., Li, S., 2011. China's lakes at present: number, area and spatial distribution. Sci. China Earth Sci. 41 (3), 394-401.

Marce, R., Obrador, B., Morgui, J.A., Riera, J.L., Lopez, P., Armengol, J., 2015. Carbonate weathering as a driver of CO2 supersaturation in lakes. Nat. Geosci. 8 (2), 107-111.

Mattsson, T., Kortelainen, P., Laubel, A., Evans, D., Pujo-Pay, M., Räike, A., Conan, P., 2009. Export of dissolved organic matter in relation to land use along a European climatic gradient. Sci. Total Environ. 407 (6), 1967-1976.

Ministry of Environmental Protection of the People's Republic of China (MEPC), 2015. China Environment Bulletin (CEB), Beijing, China.

Pacheco, F.S., Roland, F., Downing, J.A., 2013. Eutrophication reverses whole-lake carbon budgets. Inland Waters 4, 41-48.

Philips, F.M., 2010. Soil-water bypass. Nat. Geosci. 3, 77-78.

Raymond, P.A., Hartmann, J., Lauerwald, R., Sobek, S., McDonald, C., Hoover, M., Butman, D., Striegl, R., Mayorga, E., Humborg, C., Kortelainen, P., Duerr, H., Meybeck, M., Ciais, P., Guth, P., 2013. Global carbon dioxide emissions from inland waters. Nature 503 (7476), 355-359.

Roland, F., Vidal, L.O., Pacheco, F.S., Barros, N.O., Assireu, A., Ometto, J., Cimbleris, A., Cole, J.J., 2010. Variability of carbon dioxide flux from tropical (Cerrado) hydroelectric reservoirs. Aquat. Sci. 72 (3), 283-293.

Shen, T., Li, W., Pan, W., Lin, S., Zhu, M., Yu, L., 2017. Role of bacterial carbonic anhydrase during $\mathrm{CO} 2$ capture in the $\mathrm{CO} 2-\mathrm{H} 2 \mathrm{O}$-carbonate system. Biochem. Eng. J. 123, 66-74.

Shi, K., Zhang, Y.L., Zhu, G.W., Qin, B.Q., Pan, D.L., 2018. Deteriorating water clarity in shallow waters: evidence from long term MODIS and in-situ observations. Int. J. Appl. Earth Obs. Geoinf. 68, 287-297.

Sobek, S., Tranvik, L.J., Prairie, Y.T., Kortelainen, P., Cole, J.J., 2007. Patterns and regulation of dissolved organiccarbon: an analysis of 7,500 widely distributed lakes.

Limnol. Oceanogr. 52 (3), 1208-1219. 
Song, K.S., Zang, S.Y., Zhao, Y., Li, L., Du, J., Zhang, N.N., Wang, X.D., Shao, T.T., Liu, L., Guan, Y., 2013. Spatiotemporal characterization of dissolved carbon for inland wa- ters in semi-humid/semiarid region, China. Hydrol. Earth Syst. Sci. 10 (5), 6559-6597.

Song, K.S., Wang, M., Du, J., Yuan, Y., Ma, J., Wen, Z.D., 2016. Spatiotemporal variations of lake surface temperature across the Tibetan Plateau using MODIS LST product.

Remote Sens. 8 (10), 854-900.

Spencer, R.G.M., Butler, K.D., Aiken, G.R., 2012. Dissolved organic carbon and chromophoric dissolved organic matter properties of rivers in the USA. J. Geophys. Res. 117, 14 G03001.

Sugiyama, Y., Anegawa, A., Kumagai, T., Harita, Y., Hori, T., Sugiyama, M., 2004. Distribution of dissolved organic carbon in lakes of different trophic types. Limnology 5 (3), 165-176.

Tobias, C., Boehlke, J.K., 2011. Biological and geochemical controls on diel dissolved inorganic carbon cycling in a low-order agricultural stream: implications for reach scales and beyond. Chem. Geol. 283 (1-2), 18-30.

Tranvik, L.J., Downing, J.A., Cotner, J.B., et al., 2009. Lakes and reservoirs as regulators of carbon cycling and climate. Limnol. Oceanogr. 54 (6), 2298-2314.

Urban, N.R., Auer, M.T., Green, S.A., Lu, X., Apul, D.S., Powell, K.D., Bub, L., 2005.

Carbon cycling in Lake Superior. C06S90. J. Geophys. Res. 110. http://dx.doi.org/ 10.1029/2003JC002230.

Wang, S., Dou, H., 1998. Chinese lake catalogue. Science Press, Beijing.

Wen, Z.D., Song, K.S., Zhao, Y., Du, J., Ma, J.H., 2016. Influence of environmental factors on spectral characteristic of chromophoric dissolved organic matter(CDOM) in Inner Mongolia Plateau, China. Hydrol. Earth Syst. Sci. 20, 787-801.

Wen, Z., Song, K., Shang, Y., Zhao, Y., Fang, C., Lyu, L., 2018. Differences in the distribution and optical properties of DOM between fresh and saline lakes in a semi-arid area of Northern China. Aquat. Sci. 80 (22), 1-12.

Wetzel, R.G., 2001. Limnology: lake and river ecosystems, third ed. Academic Press, San Diego.

Weyhenmeyer, G., Kosten, S., Wallin, M., Tranvik, L., Jeppesen, E., et al., 2015.

Significant fraction of $\mathrm{CO}_{2}$ emissions from boreal lakes derived from hydrologic inorganic carbon inputs. Nat. Geosci. 8 (12), 933-936.

Weyhenmeyer, G.A., Müller, R.A., Norman, M., Tranvik, L.J., 2016. Sensitivity of freshwaters to browning in response to future climate change. Clim. Change 134, 225-239.

Williamson, C.E., Rose, K.C., 2010. When UV meets fresh water. Science 329, 637-639. Williamson, C.E., Morris, D.P., Pace, M.L., et al., 1999. Dissolved organic carbon and nutrients as regulators of lake ecosystems: resurrection of a more integrated para- digm. Limnol. Oceanogr. 44, 795-803.

Wilson, H.F., Xenopoulos, M.A., 2008. Ecosystem and seasonal control of stream dissolved organic carbon along a gradient of land use. Ecosystems 11 (4), 555-568.

Wilson, H., Xenopoulos, M.A., 2009. Effects of agricultural land use on the composition of fluvial dissolved organic matter. Nat. Geosci. 2, 37-41.

Xu, F.L., Yang, C., He, W., He, Q.S., Li, Y.L., Kang, L., Liu, W.X., Xiong, Y.Q., Xing, B.S., 2017. Bias and association of sediment organic matter source apportionment indicators: a case study in a eutrophic Lake Chaohu, China. Sci. Total Environ. 581-582, 874-884.

Xu, H., Zheng, H., Chen, X., Ren, Y., Ouyang, Z., 2016. Relationships between river water quality and landscape factors in Haihe River Basin, China: implications for environmental management. Chinese Geographical Sci. 26 (2), 197-207.

Yang, L.B., Lei, K., Meng, W., Fu, G., Yan, W.J., 2013. Temporal and spatial changes in nutrients and chlorophyll- $\alpha$ in a shallow lake, Lake Chaohu, China: an 11-year investigation. J. Environ. Sci. 25 (6), 1117-1123.

Ye, L., Wu, X., Tan, X., et al., 2010. Cell lysis of cyanobacteria and its implications for nutrient dynamics. Int. Rev. Hydrobiol. 95, 235-245.

Ye, L., Wu, X., Liu, B., et al., 2015. Dynamics and sources of dissolved organic carbon during phytoplankton bloom in hypereutrophic Lake Taihu (China). Limnologica - Ecol. Manage. Inland Waters 54, 5-13.

Yoshioka, T., Ueda, S., Khodzher, T., et al., 2002. Distribution of dissolved organic carbon in Lake Baikal and its watershed. Limnology 3, 0159-0168.

Zhang, Y.L., Zhang, E.L., Yin, Y., Van Dijk, M.A., Feng, L.Q., Shi, Z.Q., Liu, M.L., Qin, B.Q., 
2010. Characteristics and sources of chromophoric dissolved organic matter in lakes of the Yungui Plateau, China, differing in trophic state and altitude. Limnol. Oceanogr. 55 (6), 2645-2659.

Zhang, Y.L., Zhou, Y.Q., Shi, K., Qin, B.Q., Yao, X.L., Zhang, Y.B., 2018. Optical properties and composition changes in chromophoric dissolved organic matter along trophic gradients: implications for monitoring and assessing lake eutrophication. Water Res. $131,255-263$.

Zhao, Y., Song, K.S., Wen, Z.D., Li, L., Zang, S.Y., Shao, T.T., Li, S.J., Du, J., 2016. Seasonal characterization of CDOM for lakes in semiarid regions of Northeast China using excitation-emission matrix fluorescence and parallel factor analysis (EEMPARAFAC). Biogeosciences 13, 1-11.

Zhou, Y., Zhang, Y., Shi, K., Niu, C., Liu, X., Duan, H., 2015. Lake Taihu, a large, shallow and eutrophic aquatic ecosystem in China serves as a sink for chromophoric dissolved organic matter. J. Great Lakes Res. 41 (2), 597-606.

Zhou, Y., Jeppesen, E., Zhang, Y., Shi, K., Liu, X., Zhu, G., 2016. Dissolved organic matter fluorescence at wavelength $275 / 342 \mathrm{~nm}$ as a key indicator for detection of point- source contamination in a large Chinese drinking water lake. Chemosphere 144, 503-509.

Zhou, Y., Ma, J., Zhang, Y., Qin, B., Jeppesen, E., Shi, K., Brookes, J.D., Spencer, R.G.M., Zhu, G., Gao, G., 2017. Improving water quality in China: environmental investment pays dividends. Water Res. 118, 152-159. 